\title{
TOMATO (Lycopersicon esculentum P. Miller) COMPRESSION DUE TO “K” WOOD BOX CLOSING
}

\author{
Compressão de tomate (Lycopersicon esculentum P. Miller) em função do \\ fechamento da caixa de madeira tipo " $K$ "
}

\author{
Rita de Fátima Alves Luengo ${ }^{1}$, Adonai Gimenez Calbo 2 , Angelo Pedro Jacomino ${ }^{3}$
}

\begin{abstract}
Wood boxes kind " $\mathrm{k}$ " are the most used in table tomato (Lycopersicon esculentum P. Miller) commercialization in Brazil. Due to the fruit accommodation process that occurs during the transport from the production place to the commercialization point, producers fill tomato boxes a little bit over its physical capacity, and they close it with wood strips fixed with nails. In order to prevent strips from cracking, it is common to keep them inside water before using, to increase flexibility. When boxes are opened, many fruits are cracked or kneaded in a significant part of their total area, and normally they are thrown away. The purpose of this paper was to quantify the compression tomato fruits are exposed to in consequence of the " $\mathrm{k}$ " box fill / closing system. For this study a special instrumented box was constructed with a scales plate located at the bottom, with a hydraulic load cell instrumented in the box. This instrument was then used to study the compression of fruits as the box is filled and the compression increase caused by the addition of its wooden lid. The " $\mathrm{k}$ " box closing system caused an initial compression increase 3.5 times the compression of the open tomato box, and during time as the fruits are substantially deformed. This compression was reduced two about two times de initial reference value. The consequence of this observed fruit compression is compatible with the fruit deformations and even cracks observed in the market, which are known to be relevant post harvest losses causes in the Brazilian tomato handling industry.
\end{abstract}

Index terms: Firmness, hydraulic load cell, post harvest losses, Lycopersicum esculentum, box.

\section{RESUMO}

Caixas de madeira do tipo "K" são as mais utilizadas na comercialização de tomate (Lycopersicon esculentum P. Miller) de mesa no Brasil. Em razão do processo de acomodação dos frutos que ocorre durante o transporte desde o local de produção até o local de comercialização, os produtores enchem a caixa de tomate um pouco acima de sua capacidade física e a fecham com ripas de madeira e pregos. Para evitar que as ripas rachem, é comum mantê-las imersas em água antes do fechamento, para que fiquem mais flexíveis. Quando as embalagens são abertas, muitos frutos estão rachados ou amassados em parte significativa de sua área e, normalmente, são descartados. Para este estudo, construiu-se uma embalagem cujo fundo é uma balança, com uma célula de carga hidráulica acomodada no fundo da caixa. Desse modo, a pressão que os frutos sofreram no interior da caixa com e sem o fechamento da tampa foi registrada ao longo do tempo, com auxílio de um tubo manométrico. O fechamento da caixa aumentou, inicialmente, em 3,5 vezes a compressão e depois, com a deformação plástica dos frutos, a compressão diminuiu para cerca de duas vezes em relação à compressão observada na caixa aberta. Portanto, as pressões observadas no fechamento da caixa comprimem os frutos de tomate, causando amassamento e até mesmo rachaduras. Estas injúrias têm sido observadas frequentemente na pós-colheita deste e outros produtos e são causas primárias de perdas consideráveis.

Termos para indexação: Célula de carga, firmeza, perdas pós-colheita, Lycopersicum esculentum, embalagem.

\section{(Received in september 11, 2008 and approved in august 18, 2009)}

\section{INTRODUCTION}

Wooden boxes named " $\mathrm{k}$ " remain as the most popular boxes for table tomato (Lycopersicon esculentum P. Miller) in Brazil. Due to the fruit accommodation, which occurs during the transportation from producer to the market place, the producers usually overfill tomato boxes by about $6 \%$, before the closure with nailed wooden shingles. The tension necessary for this process is so high that in order to prevent the wood from cracking, it is common to keep the shingles inside water before using, to increase their flexibility. When boxes are opened, many fruits are badly kneaded or cracked. These badly damaged fruits are normally discarded to avoid even greater losses. In a work carried out by the São Paulo Agricultural Secretary's Office (Secretaria da Agricultura, 1995), the measured post-harvest losses of tomato fruits packed in "k" wooden boxes were $34.04 \%$, and from this total 14.92 $\%$ were particularly due to this old box system.

There is a strong relationship between mechanical damages and diseases that cause fruit deterioration in the

\footnotetext{
${ }^{1}$ Embrapa Hortaliças, km 09 BR 060 - Cx. P. 218 - 70359-970 - Brasília, DF - rita@cnph.embrapa.br

Embrapa Instrumentação Agropecuária - São Carlos, SP

3Universidade de São Paulo, Escola Superior de Agricultura "Luiz de Queiroz" - Piracicaba, SP
} 
post-harvest phases. Kelman (1984) affirms that mechanical injuries are the "entrance door" for fungi and bacteria and that this problem can be reduced using properly designed boxes. Ardito (1986) working with 'Santa Cruz' tomatoes packed in cardboard and wood boxes and transported for $100 \mathrm{~km}$ and $500 \mathrm{~km}$, in real conditions and in vibration simulated conditions, observed that there was a significant difference between wood boxes and cardboard boxes in relation to mechanical injuries. Wood boxes provoked 50 and $100 \%$ more mechanical injuries than cardboard boxes, to 100 and $500 \mathrm{~km}$ treatments, respectively. This author believes that the main additional cause of the mechanical injuries in wood boxes was the friction the peripheral fruits receive against the rough box unpolished wood surfaces.

The purpose of this paper was to quantify compression in 'Carmem' tomato inside " $\mathrm{k}$ " wood box with and without cover.

\section{MATERIAL AND METHODS}

For these experiments 'Carmem' table tomato fruits were harvested at the salad ripening stage (Companhia de Entrepostos e Armazéns Gerais de São Paulo-CEAGESP, 1998). The fruits medium size and without defects were harvested at Taquara, near Brasília-DF, one day before the experiment. This index corresponds roughly to a 3 score in the USDA criteria (United State Department AgriculturalUSDA, 1985), but with less uniformity. This ripeness stage 2 is the most frequently encountered in packed tomato fruits commercialized in Brazil. The product excess accommodated in the box was based on the weight of the product in the repetitions of this experiment, expressed in percentage in relation to total weight of the box, about $6 \%$.

In order to estimate the compression received by the fruits during and after the " $k$ " box closure a hydraulic load cell instrumented wood box, with the internal dimensions of a " $k$ " box (49,5 X 35,6 X 22,0 cm), was prepared. The load cell with a balance plate was added to the box bottom. This hydraulic load cell was operated with a manometric constant volume procedure to assure the plate height remains constant also.

In Figure 1 the hydraulic load cell instrumented wooden " $k$ " box is illustrated with a sensitive Bourdon manometer. A second illustration presents the hermetic water container in detail and the aluminum weight sensitive membrane. This hydraulic load cell is similar to other hydraulic load cells described by Erdem (1982) and Silva (2005). In the other hand, Figure 2 is a photograph of the experimental set up, in which the Bourdon manometer was replaced by a more sensitive water column manometer coupled to the pipette, in which the meniscus was returned to the reference position, increasing the pneumatic air pressure before each pressure reading. Prior to the use the equipment was tested, calibrated and considered reliable for this research.

The simulated " $k$ " box closure was done with four thumb screws to allow repetitive and controlled assays with different tomato fruit samples.

The average fruit pressure inside box, with and without cover, was registered as a water column height difference. This value eventually was worked to obtain tomato product equivalent pile height according to this fruit apparent density inside a open " $\mathrm{k}$ " box, which is only an rough value used to compare with the limits set by Luengo (2005).

The representative fruit compression traces refers to at least four repetitions with very similar results. The statistical analysis was descriptive and the comparison between fruits with and without cover was made using the Student $t$ test.
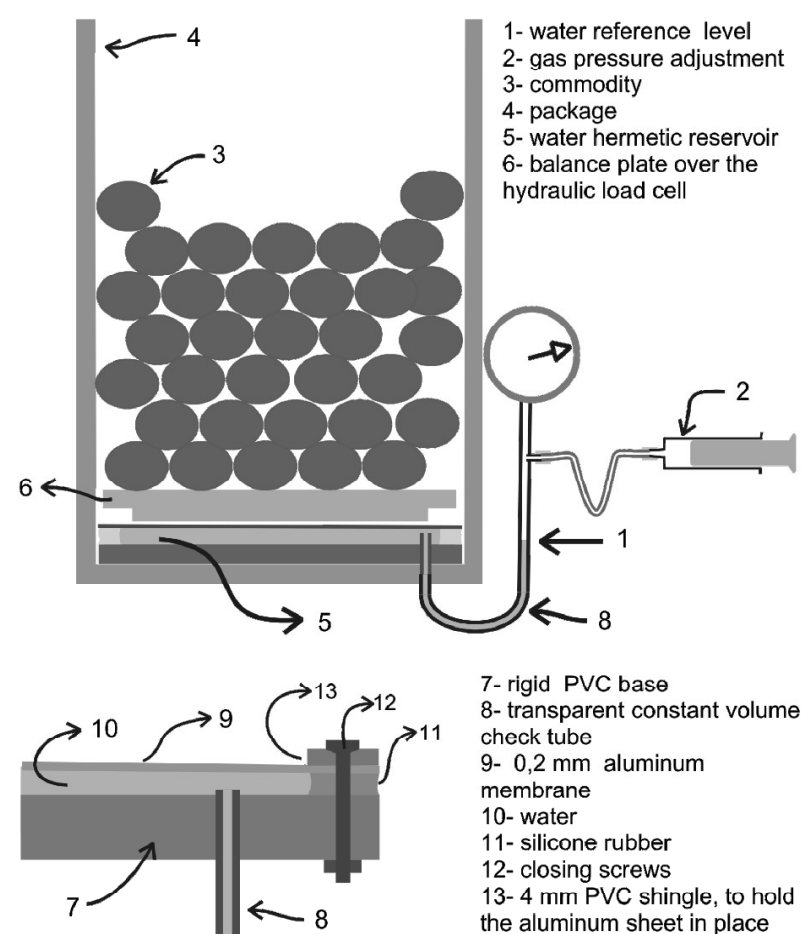

7- rigid PVC base

8- transparent constant volume check tube

9- $0,2 \mathrm{~mm}$ aluminum

membrane

10- water

1- silicone rubber

12- closing screws

13- $4 \mathrm{~mm}$ PVC shingle, to hold

the aluminum sheet in place

Figure 1 - Scheme of a hydraulic load cell, with a balance plate, placed at the bottom of the wooden assay box to observe the average pressures the fruits are subjected to. This hydraulic load cell is read after returning the meniscus to the reference position (1) by applying pneumatic pressure with a syringe (2). 


\section{RESULTS AND DISCUSSION}

The comparison between fruits compressed by closure with the wooden shingles inside tomato overfilled boxes and in open box yield was significantly different, at $1 \%$, according to the Student $t$ test. This old "k" box closing system increased the tomato fruit compression 3.5 times in relation to the tomatoes in the control boxes. Four hours after box closing the compression in tomatoes packed in covered boxes reduced to twice the pressure suffered by fruits packed in open boxes (Figure 3). This pressure reduction in time was possibly caused by plastic deformation in fruits as previously reported by Pereira \& Calbo (2000) for tomato uniaxial compression stresses. The box closing system compressed the tomatoes and allowed the occurrence of fruit cracking and kneading, which are important causes of post-harvest losses.

Fruit ripeness is an important factor that affects tomato compression tolerance. The more ripe the fruit the biggest is the fruit compression, because ripe fruits have lager plasticity and elasticity (Pereira \& Calbo, 2000).

These results about this old overfilled "K" box closing system indicate its disastrous effects to the producer, who in fact "loses" the overfilling fruit amount, which is just thrown away by the retailer. No wonder why, those fruits are sometimes referred as the "lost" fruits. The solution to this problem seems to be a better respect to the commodity compression tolerance (Luengo, 2005), which can be attended by switching the current selling bases from volumetric to a weighing procedure, such as it is currently used for other perishables. The product excess calculated in the repetitions of this experiment was $6.59 \%$ in relation to total content of the box. This value is high, and when it is added to other losses that occur in the production chain, it contributes to diminish the producer economic return (Accarini, 2000). It is necessary to manage correctly these links of the supply chain, because they have a direct relation with others, aiming to avoid wasting time, product and money (Ballou, 2001).

The compression that fruits receive is aggravated because the " $\mathrm{K}$ " box surface is made of a rough unpolished wood, against which the fruits are displaced causing mechanical injuries (Bordin, 1998; Wills et al., 1982). Soares et al. (1994) measured mechanical injuries in fruits packed in "K" box and concluded that $47 \%$ of fruits suffers abrasion marks because of the direct contact with the rough surface of the box. Moura (1995) evaluated the percentage of mechanical injuries caused to tomatoes packed in " $\mathrm{K}$ " box and verified that $11 \%$ of total fruits had mechanical injuries and this problem occurred mainly during the box closing, because the fruits are compressed and wounded in contact with wood. The boxes are used, in average, five times, depending on handling and wood quality (Topel, 1981), and consequently the probability of presence of phytopathogens increases at each new use. Moretti et al. (1998) studied the effect of mechanical injuries on tomato quality, considering internal tissues of the injured fruit. The pericarp and placentary tissues were affected by mechanical injury, with significant reductions in carotenoids, vitamin $\mathrm{C}$ and organic acids in relation to non injured tissues. Thus, specific and technified boxes are necessary. If it is necessary to close the tomato box, for example, at the wholesale sell or to avoid abrasion among fruits, then while respecting the box capacity, soft pads can be used to keep fruits in place without such excessive compression stress.

The equation that represents the pressure inside the box data distribution after the box closing was:

$$
\mathrm{y}=71,412 \mathrm{t}^{-0,1278}
$$

This time power function had a very good adjustment $(99,23 \%)$ and the rapid fruit plastic accommodation is a reasonable inference from this pressure reduction time course. As the pressure stress is reduced by the plastic accommodation additional strain is reduced and a pressure stabilization is approximated in time (Figure 4).

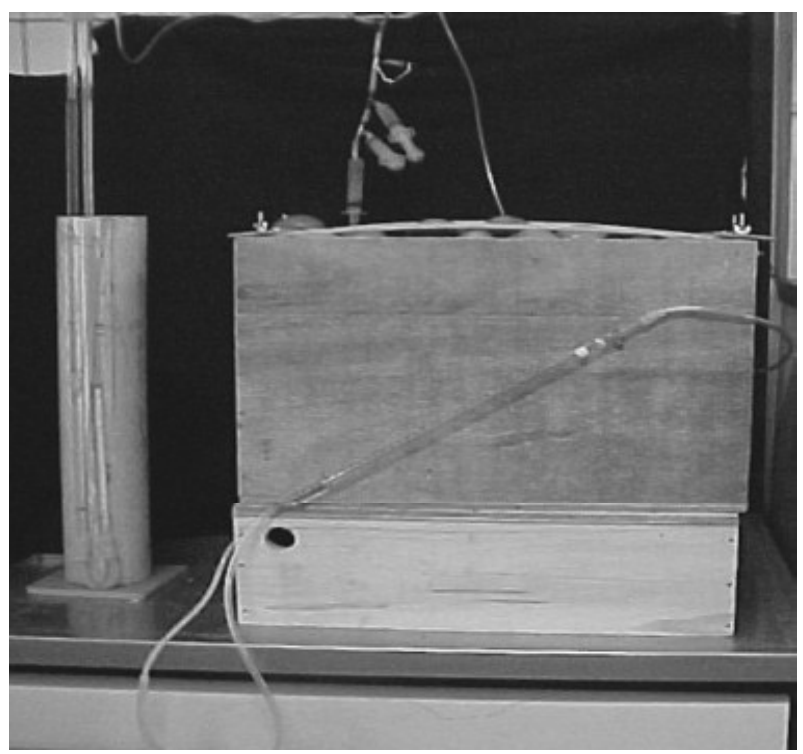

Figure 2 - Hydraulic load cell instrumented wooden box to simulate the pressures the tomato fruits experience inside of a " $k$ " wooden box, when closed after being overfilled with tomato fruits. Wooden shingles and four thumb screws were used for closure and the simulated pressure treatment. 


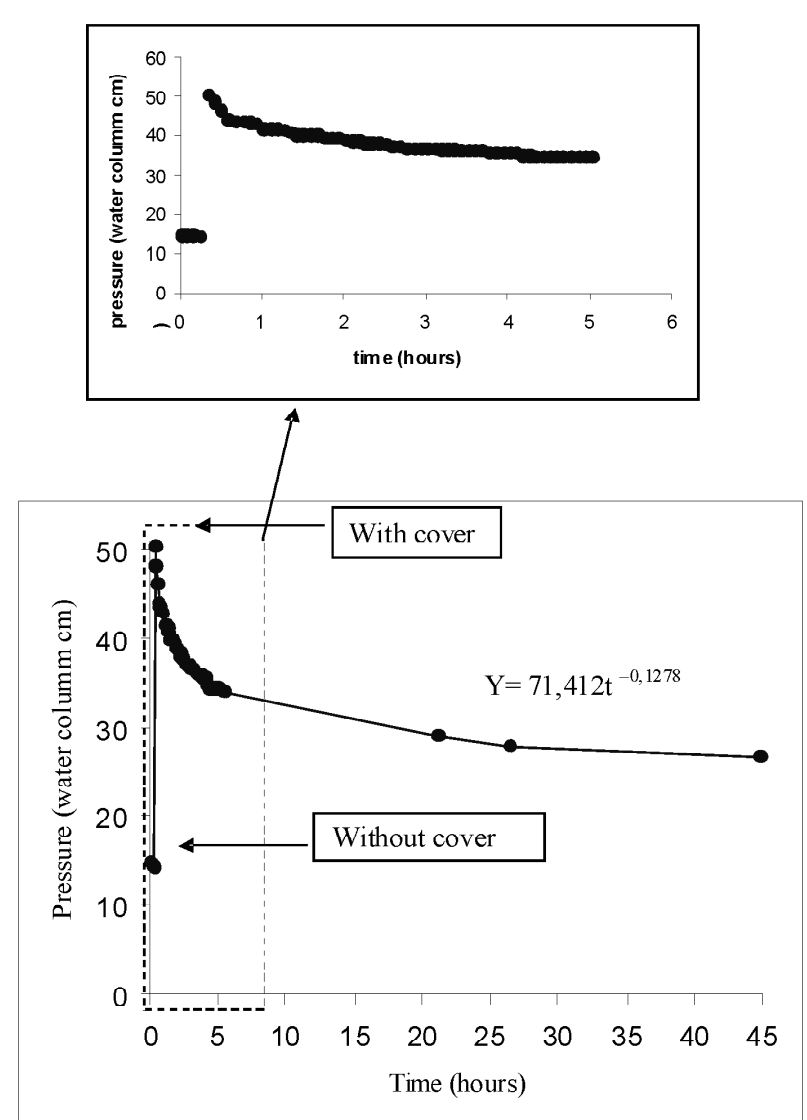

Figure 3 - Forty five hours compression traces for tomato fruits packed inside of a "K" wooden box, which was closed with aid of wooden shingles and four thumb screws, after being overfilled (6\%) with tomato fruits.

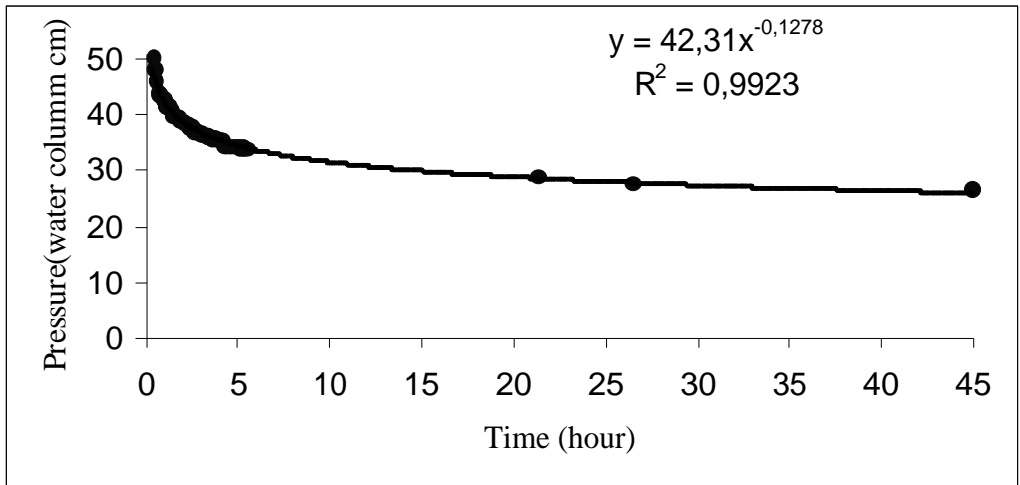

Figure 4 - Typical compression decay curve for tomato fruits packed inside of a " $K$ " wooden box, which was closed with aid of wooden shingles and four thumb screws, after being overfilled (6\%) with tomato fruits. 
The results obtained in this work can be useful to develop new models of box for horticultural products. Benzil (1998) registers that when box is adequate to protect the load post-harvest losses are reduced. Banzato (2005) affirms that boxes may be integrated in a logistic system, where short time and product quality are the main purposes, and the adequated box can avoid post-harvest losses.

\section{CONCLUSIONS}

For tomato fruits the old procedure of applying a $6 \%$ overfilling before nailing the top wooden scraps caused a characteristic stress/strain deformation pattern, with a peak 3.5 stress, which occurs during the box closure. After that, the pressure inside the box decayed as a time power function. This time-course is indicative of the occurrence of irreversible plastic strains in the fruits which where shaped by the box closing lid forces.

\section{REFERENCES}

ACCARINI, J.H.; MAZOCATO, M.A.; COSTA, O.G.P.; LUENGO, R.F.A. Hortícolas: modernização necessária. Agroanalysis, São Paulo, v.20, n.1, p.41-46, jan. 2000.

ARDITO, E.F.G. Comparison of field testing and laboratory testing for tomatoes in distribution boxes in Brazil. 1986. 62f. Dissertação (Mestrado)-Michigan State University, East Lansing, 1986.

BALLOU, R.H. Gerenciamento da cadeia de suprimentos: planejamento, organização e logística empresarial. Porto Alegre: Bookman, 2001. 532p.

BANZATO, J.M. A integração das embalagens dentro do sistema logístico. Disponível em: <http: WwW.guiadelogistica.com.bri $>$. Acesso em: 12 set. 2005.

BENZIL, L.D. Embalagens adequadas evitam perdas no setor agrícola. Revista Tecnologística, São Paulo, v.3, n.26, p.22-26, jan. 1998.

BORDIN, M.R. Embalagem para frutas e hortaliças. In: CURSO DE ATUALIZAÇÃO EM TECNOLOGIA DE RESFRIAMENTO DE FRUTAS E HORTALIÇAS, 2. 1998, Campinas. Campinas: Unicamp, 1998. p.19-27.

COMPANHIA DE ENTREPOSTOS E ARMAZÉNS GERAIS DE SÃO PAULO. Classificação de tomate. São Paulo, 1998. 1 Folder.

ERDEM, U. Force and weight measurement. Journal of Physics, Bristol, v.15, p.857-872, 1982.
KELMAN, A. Opportunities for future research in postharvest pathology. In: MOLINE, H.E. Postharvest pathology of fruits and vegetables: postharvest losses in perishable crops. BerKeley: Agricultural Experiment Station, 1984. p.76-80.

LUENGO, R.F.A. Dimensionamento de embalagens para comercialização de hortaliças e frutas no Brasil. 2005. 75f. Tese (Doutorado em Fitotecnia)-Escola Superior de Agricultura Luiz de Queiroz, Piracicaba, 2005.

MORETTI, C.L.; SARGENT, S.; HUBER, D.J.; CALBO, G.; PUSCHMANM, R. Chemical composition and physical properties of pericarp, locule, and placental tissues of tomatoes with internal bruising. Journal of the American Society for Horticultural Science, Geneva, v.123, n.4, p.656-660, 1998.

MOURA, R. Danos mecânicos no tomate, pelo uso da caixa K. In: CONGRESSO BRASILEIRO DE OLERICULTURA, 35., 1995, Foz do Iguaçu. Resumos... Foz do Iguaçu: SOB, 1995. p.110.

PEREIRA, A.V.; CALBO, A.G. Elastic stresses and plastic deformations in 'Santa Clara' tomato fruits caused by box dependent compression. Pesquisa Agropecuária Brasileira, Brasília, v.35, n.12, p.2429-2436, 2000.

SILVA, T.J.A. da. Evapotranspiração e coeficiente de cultivo de maracujazeiros determinados pelo método do balanço de radiação e lisimetria de pesagem hidráulica. 2005. 99f. Tese (Doutorado em Fitotecnia)- Escola Superior de Agricultura Luiz de Queiroz, Piracicaba, 2005.

SOARES, G.; COREEA, T.B.S.; SARGENT, S.; ROBBS, C.F. Perdas na qualidade do tomate na cadeia produtiva. Rio de Janeiro: Embrapa/CTAA, 1994. 7p.

TOPEL, R.M.M. Estudos de embalagens para produtos hortícolas: o caso da caixa K. São Paulo: IEA, 1981. 29p.

UNITED STATES DEPARTMENT AGRICULTURAL. USDA color classification requirements in United States standards for grades of fresh tomatoes. Washington, 1985. Visual Aid TM-L-1.

WILLS, R.B.H.; IEE, T.H.; GRAHAM, D.; McGLASSON, W.B.; HALL, E.G. Postharvest: an introduction to the physiology and handling of fruits and vegetables. Westport: AVI, 1982. 161p. 